\title{
ORKES SIMFONI DALAM PERSPEKTIF HABITUS BOURDIEU
}

\author{
Y. Edhi Susilo \\ Fakultas Seni Pertunjukan Institut Seni Indonesia Yogyakarta \\ Email:edhisus@yahoo.com \\ Timbul Haryono \\ Fakultas Ilmu Budaya Universitas Gadjah Mada \\ Victor Ganap \\ Fakultas Seni Pertunjukan Institut Seni Indonesia Yogyakarta
}

\begin{abstract}
Symphony orchestra in Indonesia according to the perspective of "habitus Bourdieu" has managed to create a middle-class symphony orchestra music. Habitus is in the process of producing and reproducing the group, and when the group was awakened, finally realizing that he is a group. The existence of a symphony orchestra in Indonesia was pioneered by Radio Orchestra and Orchestra Studio in RRI Jakarta in 1950. In 1966 on the initiative of Ali Sadikin, both the orchestra and being joins with name Orkes Simfoni Jakarta (OSJ). OSJ as outset of symphony orchestra in Indonesia, further influencing the emergence of various symphony orchestras such as: University of Indonesia Symphony Orchestra (1983), Twilite Orchestra (1991), Surabaya Symphony Orchestra (1996), Nusantara Symphony Orchestra (2000), Gita Bahana Nusantara (2003), and others.
\end{abstract}

Keywords: Bourdieu's habitus, symphony orchestras, the middle class.

\section{ABSTRAK}

Orkes simfoni di Indonesia menurut perspektif "habitus Bourdieu" telah berhasil membuat sebuah kelas menengah musik orkes simfoni. Proses di dalam habitus adalah memproduksi dan mereproduksi kelompok, dan ketika kelompok itu tersadarkan, akhirnya menyadari bahwa dirinya adalah sebuah kelompok. Keberadaan orkes simfoni di Indonesia dipelopori oleh Orkes Radio dan Orkes Studio di RRI Jakarta pada tahun 1950. Pada tahun 1966 atas prakarsa Ali Sadikin, kedua orkes tersebut bergabung dan menjadi Orkes Simfoni Jakarta (OSJ). OSJ sebagai cikalbakal orkes simfoni di Indonesia, selanjutnya mempengaruhi munculnya berbagai macam orkes simfoni seperti: Orkes Simfoni Universitas Indonesia (1983), Twilite Orchestra (1991), Surabaya Symphony Orchestra (1996), Nusantara Symphony Orchestra (2000), Gita Bahana Nusantara (2003), dan lain-lain.

Kata kunci: habitus Bourdieu, orkes simfoni, kelas menengah. 


\section{PENGANTAR}

Pada ilmu sosial bahwa Bourdieu mengatakan dalam kehidupan sosial tidak dapat dipahami semata-mata sebagai sebuah gregat perilaku individu. Dia tidak dapat menerima bahwa praksis dapat dipahami secara terpisah dalam hal pengambilan keputusan individu di satu sisi, atau sebagai sesuatu yang ditentukan oleh struktur supra individual. Habitus merupakan usaha membangun jalan yang melintasi jurang ekplanatori dari uraian sebelumnya. Di samping itu, habitus adalah sebuah sistem skema generatif yang didapatkan dan disesuaikan secara obyektif dengan situasi dan kondisi spesifik di mana dia dibangun. Habitus menurut pemikiran secara obyektif, disesuaikan dengan kondisi di mana dia dibentuk. Habitus berperan membimbing aktor untuk melakukan sesuatu hal, dia menyediakan suatu basis bagi pembentukan praksis. Praksis diproduksi di dalam dan oleh interaksi antara habitus dan disposisinya. Habitus adalah produk sejarah, menghasilkan praksis individual dan kolektif menurut skema yang dibangun sejarah. Sementara itu sejarah adalah satu rangkaian berlanjut dari hasil yang akan tampak (probabilitas). Mereka adalah produk dari apa yang dilakukan orang (praksis). Pada gilirannya praksis merupakan produk habitus, sekaligus berperan untuk mereproduksi atau mengatakannya sebagai sesuatu yang benar, dan habitus adalah suatu kulminasi sejarah yang terus berlanjut.

Orkes simfoni hadir di Indonesia pertamakali pada tahun 1950 di RRI Jakarta dengan nama Orkes Radio dan Orkes Studio. Selanjutnya pada tahun 1966 kedua orkes tersebut digabungkan dan menggunakan nama Orkes Simfoni Jakarta (OSJ). Para pelaku yang terdiri dari pemain, konduktor, penikmat, dan pendukung OSJ telah berhasil mengembangkan dunia orkes simfoni di Indonesia dengan memproduksi dan mereproduksi berbagai macam orkes simfoni. Perkembangan saat ini adalah orkes simfoni dapat ditemukan diberbagai kota di Indonesia.
Pertanyaan yang dimunculkan sebagai berikut: (1)Apakah perkembangan orkes simfoni di Indonesia, sejalan dengan teori habitus Pierre Bourdieu?(2) Mengapa orkes simfoni dapat dapat berkembang di Indonesia? Guna menjawab pertanyaanpertanyaan tersebut, penulis berusaha menguraikan sekilas tentang teori habitus Bourdieu dan memaparkan geliat musik orkes simfoni di Indonesia sejak tahun 1950 hingga kini. Metode yang digunakan adalah metode sejarah (yang ditunjukkan dengan penyebutan waktu dan tahun secara kronologis dan holistik) dan metode kualitatif menjadi alat pembedahnya. Metode kualitatif mengutamakan cara kerja dengan cara menjabarkan data yang ditemukan dan kualitatif dimaksudkan sebagai jenis penelitian yang temuan-temuannya tidak diperoleh melalui prosedur statistik atau bentuk hitungan lainnya. Dengan demikian pembahasan yang terjadi, tentunya dilaksanakan menurut teori dan metode.

\section{PEMBAHASAN}

Orkes simfoni sebagai sebuah habitus sudah berlangsung di Indonesia, perjalannanya diwarnai dengan perubahanperubahan pada kondisi yang melingkupinya serta para pelaku orkestra yang mendukungnya. Pada sub-artikel ini, akan diuraikan keberadaan orkes simfoni sejak tahun 1950-an hingga kondisi saat ini. Sekitar tahun 1950-an, di Indonesia muncul sebuah seni masyarakat baru yang disebut sebagai seni pertunjukan musik orkestra simfoni. Kemunculan jenis musik ini difasilitasi oleh pemerintahan kolonialis Belanda yang menganut budaya Eropa, dan ingin memajukan program kesenian melalui radio. Hal ini dilakukan sebagai hiburan bagi orang-orang Belanda dan orang asing yang berada di Indonesia. Selain itu juga dapat dipandang sebagai usaha melestarikan salah satu kebudayaannya di Hindia Belanda.

Indonesia kemudian memanfaatkan jenis orkestra simfoni itu untuk mengiringi lagu kebangsaannya. Selanjutnya jenis musik orkestra simfoni ini mulai dipelajari 
masyarakat Indonesia dengan belajar langsung dari orang Belanda ataupun orang asing lainnya yang berada di Indonesia. Di samping itu pada awal 1950-an itu, beberapa kaum pejuang yang terpelajar dan mendapat pendidikan apresiasi musik di sekolah-sekolah Belanda sering terlibat dalam pergaulan musik di RRI. Pada perkembangannya, banyak orang Indonesia yang belajar musik orkestra simfoni di negara-negara Eropa atau negara lain yang sudah memiliki pendidikan jenis musik orkestra simfoni.

Transformasi di bidang pendidikan seni musik berpengaruh luas terhadap bertambahnya kelas menengah terdidik yang siap berperan serta dalam menggeluti musik orkestra simfoni, walaupun profesi mereka berbeda-beda. Status mahasiswa, siswa, guru, dosen, seniman musik, bahkan dari militer, ataupun profesi lainnya yang kesemuanya itu akhirnya menyatu dalam musik orkestra simfoni. Dengan meningkatnya industri, Indonesia mengalami proses perubahan sosial, masuknya ekonomi dunia ketengah ekonomi nasional pada dasawarsa 1970 hingga 1980-an mempunyai akibat yang sangat jauh. Perkembangan kehidupan kota mulai bergeser, kota-kota besar mulai menjadi metropolitan yang menyajikan bentuk masyarakat yang berbeda sangat jauh dengan pedesaan.

Hal yang menarik dalam perubahan itu telah mempengaruhi para birokrat di Indonesia, Jakarta telah menjadi kota metropolitan dan ketika Ali Sadikin menjadi Gubernur DKI (1966-1977) mulai melengkapi kebutuhan-kebutuhan kota metropolitan. Salah satu di antaranya adalah adanya musik simfoni pada kota-kota metropolitan di manca negara. Ali Sadikin kemudian memprakarsai dan membiayai pendirian Orkes Simfoni Jakarta. Pendirian orkes simfoni ini menjadi semacam klaim bahwa musik orkestra simfoni bukan merupakan milik Barat saja, tetapi musik orkestra simfoni sudah menjadi budaya global dan universal. Kondisi seperti ini diperkuat dengan ajakan PBB untuk mengadakan musik orkestra simfoni dunia pada tahun 1971 dalam World Simphony Orchestra. Selain itu kegiatan negara-negara Asean dalam Asean Youth Music Workshop yang sudah dimulai sejak tahun 1980 di Malaysia, selalu melibatkan musik orkestra simfoni. Tanggal 7 Januari 1991, pemuda-pemudi ASEAN mengadakan pergelaran musik orkestra simfoni diGedung Graha Bhakti Budaya Taman Ismail Marzuki Jakarta. Konser tersebut dalam rangka Latihan Kerja Musik untuk para remaja ASEAN, konduktor pergelaran ini adalah Adhidarma dan Jazeed Djamin.

Mengapa kemakmuran ekonomi, status sosial dan posisi kelas mendorong mereka pada intensitas musik orkestra simfoni? Mengapa perubahan sosial yang cepat yang mengakibatkan sekularisasi kebudayaan justru menimbulkan sikap untuk berkesenian musik orkestra simfoni? R.M. Soedarsono mengatakan bahwa di negara-negara maju yang tata kehidupannya mengacu pada budaya industrial, yaitu semua hal dapat diukur dengan uang, hampir semua bentuk-bentuk seni pertunjukan merupakan sajian estetis, yang khusus untuk dinikmati keindahannya. Seandainya penikmatnya adalah penonton yang harus membayar, selanjutnya seni pertunjukan tersebut berfungsi sebagai presentasi estetis. Oleh karena itu, penontonnya membayar, maka dibutuhkan penggarapan yang sangat seriuskarena penontonnya menuntut pertunjukan yang baik. Seni pertunjukan estetis di Indonesia, muncul pada akhir abad 19, ketika tumbuh kota-kota yang penduduknya tidak tergantung pada sektor pertanian. Manusia yang berperilaku estetis (aesthetis behavior), secara naluriah mereka ingin menikmati sajian-sajian estetis. Mereka menginginkan bentuk-bentuk pertunjukan yang dapat dinikmati dengan membeli karcis yang tidak terikat oleh tempat dan waktu. Pertunjukan estetis berkembang jika para penikmatnya memiliki penghasilan mencukupi, sehingga mereka dapat menyisihkan sebagian penghasilan untuk kepentingan rekreasi. Masa perkembangan seni pertunjukan sebagai sebuah presentasi 
estetis di Indonesia terjadi pada tahun 1950an.

Ketika masyarakat pendukung musik orkestra simfoni mulai berkembang, intensitas berkesenian menjadi meningkat. Dalam menggapai pertunjukan estetis, selanjutnya bagaimana mereka "membentuk diri" menjadi sebuah kelas? Sebuah kelas sebagai sebuah identitas kolektif dibentuk oleh banyak kode-kode sosial tergantung dari bentuk kesetiaan, komitmen, atribut, dan afiliasi yang menentukannya. Selain itu, cara berpakaian, cara menyajikan, dan menikmati seni pertunjukan dan juga dalam berperilaku. Tampilnya kode-kode mengikat anggotaanggota dan memunculkan simbol-simbol kelompok hingga menjadi sebuah identitas kolektif. Identitas kolektif dibentuk oleh beberapa kode kelas. Pada konteks inilah, di Indonesia sejak tahun 1980-an, saluran ekspresi musikal yang berkembang luas sebagai kode-kode yang saling menunjang dan melengkapi telah membentuk kelas sosial baru, yaitu kesadaran sebagai kelas musik simfoni. Kode yang ada itu melebihi dari sekedar kode politik dan ekonomi,yaitu kode kultural seni pertunjukan.

\section{Habitus dan Kehadiran Orkestra Simfoni}

Kelas sosial ekonomi baru sebagai kelas menengah ini secara luas adalah pekerja dan penikmat seni musik di wilayah-wilayah perkotaan. Kelas menengah musik simfoni mulai terbentuk dengan unsur-unsurnya seperti kaum profesional, modernis, aktivis kegiatan sosial, ekonomi dan kebudayaan, dan tidak tertarik lagi kepada orientasi politik lama, yaitu menganggap bahwa musik simfoni hanya diperuntukan bagi orang asing. Keberadaan kelas menengah musik simfoni didorong oleh proses urbanisasi yang terjadi sejak tahun 1960 hingga tahun 1970an. Proses industrialisasi dan pembangunan yang sentralistik telah mendorong timbulnya proses urbanisasi kaum pekerja seni dari daerah ke kota metropolitan. Di tengahtengah kultur kehidupan metropolis, mereka dihadapkan pada situasi tarik-menarik antara tuntutan menjadi modern di satu sisi, tetapi dengan resiko terjangkit alienasi dan dislokasi, dan bagaimana mempertahankan akar-akar kultur musik simfoni dengan resiko kehilangan modernitas dalam dunia musik hiburan. Hal ini menjadi sebuah dilema, para pelaku musik simfoni urban merasa sakit untuk sepenuhnya modern, walaupun pada perkembangannya kemudian musik simfoni dapat berpadu dengan jenis musik yang lain baik seni popular maupun etnik.

Bagaimana membuktikan kehadiran kelas musik orkestra simfoni di Indonesia, dan bagaimana melihat bahwa kelas ini telah benar-benar hadir di tengah-tengah masyarakat? Deskripsi ini berlandaskan pada perspektif Bourdieu tentang habitus dan kultural kapital dalam melihat terjadinya proses-proses sosio kultural tentang pembentukan kelas musik orkestra simfoni. Habitus adalah sebuah ekspresi dalam bentuk investasi sikap yang tidak disadari di sebuah ruang publik dalam konteks kekuasaan. Habitus adalah sebuah pedoman aksi yang dilakukan untuk membedakan sebuah kelas (kelas dominan) dari yang kelas yang lain (yang didominasi) dalam kehidupan sosial. Habitus adalah pembiasaan sikap yang dilakukan berulang-ulang atau membuat tindakan sosial menjadi biasa (natural) sehingga muncul kebiasaan yang terlembagakan oleh anggota masyarakat dan akhirnya membentuk sebuah identitas dan kelas sosial baru. Dalam Disctingtion, Bourdieu mengatakan:

"This Logic doubtless helps to explain how the legitimate disposition that is acquired by frequent contact with a particular class of works"(Richard Nice, 1986:26).

Pembiasaan berulang-ulang ini dilakukan secara sadar atau tidak sadar. Sesuai perjalanan waktu, pembiasaan, atau naturalisasi tindakan akhirnya membentuk sebuah kultur baru. Hal ini kultur kelas menengah dalam waktu yang panjang karena individu atau aktor yang melakukan pembiasaan itu, menurut Bourdieu (1977) mereka tidak tahu apa yang sedang mereka 
lakukan, apa yang mereka lakukan itu bermakna jauh dari yang mereka sadari (Bourdieu, 1977: 79).

\section{Presentasi Kultural Kelas Orkestra Simfoni}

Berbeda dengan kajian-kajian umum tentang kelas menengah yang selama ini diidentifikasi sebagai sebuah fenomena ekonomi, uraian ini akan melihat kelas dari sisi yang belum pernah dilakukan yaitu sebagai presentasi kultural. Kemakmuran ekonomi adalah basis dari proses kehadiran mereka, tetapi kehadiran kelas ini tidak selalu harus ditatap secara ekonomi. Penghampiran budaya menjadi menarik karena merupakan sesuatu yang baru atau belum pernah dilakukan.

Keberadaan orkes simfoni yang sebagai salah satu bagian dari hiburan massa internasional, telah menanamkan pengaruh pada kehidupan khalayak dunia ketiga termasuk Indonesia lewat konvergensi gaya hidup yang berlandaskan pada alasan yang berbeda-beda di antara berbagai lapisan sosial. "kaum elite" memperhatikan hiburan massa ini agar dianggap tidak ketinggalan zaman dari cita rasa dan gaya hidup kekinian dari rekan-rekan satu kelasnya di luar negeri. Sedangkan "kaum menengah" mengikutinya demi aspirasi dan antisipasi, yaitu untuk mempelajari dan meniru apa yang menjadi taste dunia, dan bagaimana pola atau gaya bergerak untuk naik kelas. Akhirnya "kelas rendahan" memperhatikan karena terpukau oleh gebyar yang membuatnya terkesima dan terbuai oleh impian dan lamunan yang mampu menghanyutkannya dari kesulitankesulitan yang dihadapinya sehari-hari (Hardjana, 1993: 17-18).

Presentasi kultural orkes simfoni Nusantara Chamber Orchestra sekitar tahun 1990, telah mengawali presentasi kelompok orkes simfoni seperti: Twilight Orchestra, Erwin Gutawa Orchestra, Indonesia Philharmonic Orchestra, dan Cisya Kencana, mengkodekan meningkatnya minat masyarakat luas pada umumnya untuk dapat menikmati sajian repertoar simfonis dari musik orkestra simfoni. Pergelaranpergelaran orkes simfoni secara komersial tersebut berlangsung di Jakarta, Bandung, Surabaya dan Yogyakarta, dan diminati oleh masyarakat (Ganap, 2000:195).

New York Philharmonic Orchestra telah mengadakan tour konser ke 337 kota, 44 negara dan 5 benua, mengadakan presentasi kultural yang berupa pergelaran orkes simfoni untuk pertama kali di Indonesia pada bulan September 1984. Kehadirannya dianggap tepat karena ketika itu penonton musik orkestra di Indonesia sedang mengharapkan sesuatu yang besar dan mengagumkan, dan perkembangan musik di Indonesia sedang mengalami masa subur (Hardjana, 2004:10).

Bourdieu mengatakan bahwa tentang karya seni dalam cara-caranya yang paling artistik, yaitu sebagai sebuah penanda yang tidak menandakan apapun selain dirinya sendiri, tidak akan bisa terjadi tanpa mengaitkannya dengan hal-hal yang lain selain dirinya sendiri. Entah secara emosional atau intelektual, tetapi terjadi dengan mengenali ciri-ciri stilitistiknya yang distingtif dengan mengaitkannya kepada serangkaian karya lain yang membentuk suatu kelas tempat karya tadi berada, dan hanya kepada karya-karya ini saja.

Dari kerangka Bourdieu ini, akan dilihat beberapa fenomena yang terjadi dengan hadirnya musik simfoni di Indonesia: (1) kehadiran Orkes Simfoni Jakarta; (2) pelaku musik simfoni; (3) orkestra simfoni pada lembaga pendidikan formal; dan (4) munculnya berbagai macam musik simfoni di Indonesia. Keempat fenomena itu akan dilihat tidak hanya sekadar bukti telah meningkatnya ekspresi musikal masyarakat khususnya dalam musik orkestra simfoni, tetapi lebih dari itu, dapat dilihat sebagai apa yang disebut Bourdieu. Bourdieu mengatakan bahwa permainan bebas bagi hukum-hukum transmisi kultural dan demi struktur distribusi modal kultural yang akan ditambahkan kepada modal kultural dan demi struktur distribusi modal kultural di antara kelas-kelas sosial yang 
kemudian direproduksi. Sebagai reproduksi kultural yaitu investasi sosial yang secara generatif (terus-menerus) dilakukan dan secara perlahan kemudian meneguhkan terbentuknya sebuah identitas kelas baru bernama kelas musik orkes simfoni (data mengenai hal ini sudah tertuang dalam judul sub bab $f$, yaitu munculnya berbagai macam orkes simfoni di Indonesia)

Mengapa kemakmuran ekonomi, status sosial danposisi kelas mendorong mereka pada intensitas berolah musik? Mengapa perubahan sosial mengakibatkan sekularisasi kebudayaan justru mendorong sikap untuk menekuni musik absolut? Dalam teori dari Adoplh S. Tomars dan Janet Wolf dua orang sosiolog yang peduli terhadap seni yang dikutip R.M. Soedarsosno (2002), dikatakan bahwa pada masyarakat korporat, seni yang berkembang di kalangan masyarakat cenderung seragam, sedangkan pada masyarakat yang kompetitif, akan hadir seni yang banyak gaya dan ragamnya karena setiap seniman ingin mengetengahkan jati dirinya. Selanjutnya R.M. Soedarsono juga mengutip pendapat Wolf yang dengan tegas mengatakan bahwa seni adalah produk masyarakat (Soedarsono, 2002: 272-273). Dengan demikian dapat diasumsikan bahwa masyarakat yang menghadiri kesenian, sangat mengharapkan hadirnya bentuk serta gaya seni yang sesuai dengan selera estetis mereka. Maka dari itu, akan hadir karyakarya seni seperti yang telah dituliskan oleh Adoplh S. Tomas dan Janet Wolf.

Akses menuju karya-karya seni tidak bisa didefinisikan semata-mata menurut aksebilitas fisik karena karya-karya seni hadir hanya bagi mereka yang memiliki cara-cara memahaminya. Pemahaman melibatkan sebuah operasi pengkodean, dan kemampuan untuk mengkodekan karya seni yang memang dimaksudkan untuk dikodekan dengan cara tertentu, yaitu menurut nilai-nilai yang ditetapkan di dalam arena. Arena adalah sebuah semesta sosial terpisah yang memiliki hukum-hukum keberfungsiannya sendiri. Hal yang terikat oleh hukum-hukum keberfungsian politik dan ekonomi (a separate social universe having its own laws of fungtioning indepedent of those of politics and the economy) (Bourdieu,2012: 213). Pengkodean bukan merupakan bakat alamiah yang dimiliki semua orang karena ia melibatkan lebih banyak hal dari pada sekedar pemahaman langsung dan serta merta terhadap karya. Kopetensi seni adalah suatu bentuk pengetahuan yang mengizinkan penikmat mensituasikan karya seni dalam kaitannya dengan dunia kemungkinankemungkinan seni tempat karya itu berada (Bourdieu, 2012: xiv).

Banyak orang yang mulai tertarik pada musik orkestra simfoni, secara tidak langsung mereka mulai membentuk diri dan terbentuklah sebuah kelas. Kelas tersebut sebagai sebuah identitas kolektif, dibentuk oleh banyak kode-kode sosial tergantung dari bentuk kesetiaan, komitmen, atribut, dan afiliasi yang menentukannya. Selain itu, cara berpakaian, perilaku dalam pertunjukkan bagi penyaji maupun penikmat dalam kelas musik simfoni menimbulkan kode-kode tersendiri. Kode-kode ini mengikat "anggotaanggota" dan memunculkan simbol-simbol kelompok menjadi sebuah identitas kolektif. Identitas kolektif dibentuk oleh beberapa kode kelas. Pada konteks inilah, di Indonesia sejak berkembangnya musik orkestra simfoni menjadi saluran ekspresi yang luas sebagai kode-kode yang saling menunjang dan melengkapi telah membentuk kelas sosial baru, yaitu kesadaran sebagai kelas musik orkestra simfoni. Kode itu bukanlah sekedar kode politik dan ekonomi, tetapi berdiri sebagai kode kultural.

Kelas musik orkestra simfoni mulai terbentuk dengan unsur-unsurnya seperti: kaum profesional, modernis, aktivis kegiatan sosial, ekonomi dan kebudayaan, dan yang tertarik pada orientasi pada musik orkestra simfoni. Kelas ini terjadi juga berkat dorongan proses urbanisasi yang terjadi sejak dekade 1950 hingga 1960-an. Proses industrialisasi dan pembangunan yang sentralistik telah mendorong timbulnya proses urbanisasi kaum seniman dan musisi dari desa-desa ataupun kota-kota 
kecil yang belum memiliki musik simfoni ke wilayah-wilayah perkotaan yang telah terdapat musik orkestra simfoni. Di tengahtengah kultur kehidupan metropolis, mereka dihadapkan pada situasi tarik-menarik antara tuntutan menjadi modern di satu sisi tetapi dengan resiko terjangkit alienasi dan dislokasi, dan cara mempertahankan akarakar kultur seni musik klasik (dalam hal ini musik orkestra simfoni) dengan risiko "kehilangan" modernitas. Hal ini menjadi dilema, bagi musisi/seniman urban merasa sakit untuk sepenuhnya modern, tetapi juga sakit untuk sepenuhnya meninggalkan tradisionalitasnya, yaitu berupa kesenian ataupun budaya yang dahulu melingkupinya.

Untuk membuktikan bahwa kelas musik orkestra simfoni telah benar-benar hadir di Indonesia, tulisan ini menggunakan perspektif Bourdieu tentang 'habitus' dan 'cultural capital' dalam melihat prosesproses sosial kultural dalam pembentukan kelas musik simfoni. Habitus adalah sebuah pedoman aksi yang dilakukan untuk membedakan sebuah kelas (kelas dominan) dari yang kelas yang lain (yang didominasi) dalam kehidupan sosial. Habitus adalah pembiasaan sebuah sikap yang dilakukan secara berulang-ulang atau membuat tindakan sosial hingga menjadi biasa (natural) karena muncul kebiasaan yang menjadi terlembagakan oleh anggota masyarakat dan akhirnya membentuk sebuah identitas dan kelas sosial baru. Pembiasaan secara berulang-ulang ini dilakukan, baik secara sadar ataupun tidak sadar. Sesuai dengan perjalanan waktu, pembiasaan ini, atau naturalisasi tindakan ini, akhirnya membentuk sebuah kultur baru. Hal ini kultur kelas musik orkestra simfoni dalam waktu yang panjang karena individu atau para aktor yang melakukan pembiasaan itu.

Kultur kelas musik orkestra simfoni di Indonesia berbeda dengan kelas musik simfoni di negara Barat. Jika orkes simfoni Barat mempergelarkan karya, yang ditampilkan adalah repertoar standar orkestra. Sementara itu jika orkes simfoni Indonesia mengadakan konser, sebagian repertoar yang disajikan tentu juga menyajikan karya yang berasal dari Indonesia. Data yang menunjukkan hal itu, tertuang dalam buklet-buklet pergelaran OSJ maupun buklet orkes simfoni di Indonesia lainnya. Misalnya pergelaran orkes simfoni 'Jakarta Concert Orchestra' yang berlangsung pada tanggal 14 September 2013, selain menampilkan karya Overture to Promotheus dan Piano Concerto nomor 5 dari L.v. Beethoven juga memainkan orkestrasi lagu Nyanyian Gembira, Lagu Bagi Pahlawan, Segala Puji, dan Varia Ibu Kota, karya Muhtar Embut.

\section{Kehadiran Orkes Simfoni Jakarta}

Judul kehadiran OSJ di sini dihadirkan dalam konteks habitus Bourdieu. Sebagai ciri pertama yang menonjol tentang kehadiran kelas musik orkestra simfoni di Indonesia, ditandai oleh munculnya fenomena orkestra simfoni yang berada di RRI Jakarta, yang muncul sejak sekitar tahun 1950-an. Pergelaran OSJ yang pada awal kelahirannya hanya berada di dalam RRI Jakarta, selanjutnya mulai mengadakan pergelaran di luar RRI seperti, Hotel Indonesia dan Taman Izmail Marzuki. Setelah sekian lama musik orkestra simfoni berada dalam posisi marjinal dan merasa tereliminasi secara politik dan kultural, kemudian menjadi sebuah identitas baru dan mulai mendapatkan penikmat. (ketika itu masyarakat di Indonesia belum terbiasa dengan musik orkestra simfoni, dan awal keberadaan musik orkestra simfoni di Indonesia berasal dari budaya Barat dan diperuntukan bagi orang Barat yang berada di Indonesia). Gubernur DKI Surjadi Soedirja kala itu mengatakan suatu kebanggaan tersendiri bahwa dalam peringatan kota Jakarta yang ke 466 dapat menampilkan Orkes Simfoni Jakarta, yang dalam beberapa kali pergelarannya ternyata berhasil memikat kalangan penggemar musik klasik di ibukota. Gubernur berkeinginan agar OSJ dapat bertahan terus.

Identitas musik yang berupa musik orkestra simfoni telah menjadi perhatian para pecinta seni musik di kota besar Jakarta, di mana pada saat sebelumnya terisolsasi 
dalam kelompok kecil yang kemudian tersosialisasi secara lamban kepada masyarakat luas pecinta seni musik. Dengan digunakannya musik simfoni sebagai iringan lagu kebangsaan Indonesia Raya atas usul Yusuf Ronodipuro (pimpinan RRI Jakarta waktu itu) kepada Presiden Sukarno tahun 1950, mau tidak mau, akhirnya musik orkestra simfoni kemudian menyentuh ke berbagai kalangan. Ketika masuk pada kalangan menengah, musik orkes simfoni telah bermakna lain, bukan hanya ekspresi kesadaran berolah musik semata, tetapi secara sosial berfungsi sebagai peneguhan identitas dan simbol kebangkitan dari musik simfoni. Parni Hadi Direktur Utama Lembaga Penyiaran Publik dalam peresmian auditorium Juyuf Ronodipuro (2010) mengatakan bahwa peresmian ini ditandai dengan kebangkitan kembali pergelaran Orkes Simfoni Jakarta.

Pergelaran-pergelaran musik orkestra simfoni di berbagai tempat berperan efektif dalam proses kesadaran pembentukan kelas musik, karena ia berfungsi sebagai apa yang disebut Bourdieu dengan 'habitus.' Habitus adalah sistem pengulangan ekspresi penampilan (disposisi) yang kemudian berkembang menjadi struktur sosial yang berfungsi menstrukturkan struktur baru. Sistem pengulangan itu kemudian menggenerasi dan menstruksturkan praktekpraktek representasi yang secara obyektif terus berlangsung. Habitus kemudian memproduksi dan mereproduksi kelompok, ketika kelompok yang tersadarkan itu telah menyadari bahwa dirinya adalah kelompok.

Musik orkestra simfoni mulai ditampilkan dalam berbagai kesempatan, apa lagi dengan munculnya generasi musik simfoni yang di mana-mana mulai tumbuh di berbagai tempat. Penampilan musik berlangsung di RRI, Hotel, tempattempat pertunjukan kesenian, televisi, area pendidikan dan seterusnya. Kehidupan musik orkestra simfoni telah berproses dalam jangka waktu yang cukup lama, dan ia membentuk sebuah kesadaran kelompok. Sebagai contoh: Konser Jakarta
Philharmonic Orchestra tanggal 2 Juli 2004 di Gedung Kesenian Jakarta; Konser Nusantara Symphony Orchestra tanggal 5 Oktober 2009, di Balai Sarbini Concert Hall; Konser Jakarta Concert Orchestra tanggal 14 September 2013 di Aula Simfonia Jakarta Kemayoran Jakarta, dan lain sebagainya.

Di negara tetangga Malaysia juga terdapat musik orkestra, yang bernama Orkes Radio Malaya yang didirikan tahun 1961 dengan konsep big band dan jumlah pemainnya 13 orang. Tahun 1965 anggota orkestra berkembang menjadi 25 pemain, dengan penambahan para pemain instrumen gesek. Pada tahun 1963 Orkes Radio Malaya berganti nama menjadi Orkes Radio Malaysia. Tahun 1967 hingga tahun 1969 keanggotaan orkestra berkembang menjadi 38 orang pemain yang memainkan alat musik gesek, tiup, dan alat-alat musik ritmik. Tahun 1969 nama orkestra berubah menjadi Orkestra RTM, hal ini disebabkan adanya penggabungan radio dan televisi Malaysia.

Pada tahun 1989, hampir setengah dari para pemainnya meninggalkan orkestra, akibatnya orkestra hanya berkonsep pada dance band saja yang masih dipertahankan. Selanjutnya pada tahun 1992 Orkestra RTM menambah pemain dari Indonesia dan Filipina, dan pemain musiknya mencapai 25 orang. Tahun 1999 Orkestra RTM mengalami pergantian pimpinan dan setelah itu orkestra tampil pada 'Konser Getaran' pada tahun 2000 yang disertai dengan penerbitan CD. Selain itu Orkestra RTM juga mengadakan pergelaran Malam Simfoni Irama Malaysia (2006), dan Simfoni Putrajaya (2007). Pada ulang tahunnya yang ke-50 (2011) Orkestra RTM, anggota orkestra bertambah menjadi 35 orang pemain. Sejalan dengan penambahan pemain bertambah pula instrumen fagot, flute, dan obo.

Dengan melihat jumlah pemain yang ada pada Orkestra RTM yang hanya berjumlah 35 orang pemain, dapat dikatakan bahwa repertoar yang dimainkan bukanlah murni standar orkestra klasik. Dalam buku tersebut memang dikatakan bahwa pada saat ini (2011) orkestra memainkan musik berbagai 
genre seperti: pop, Jazz, fusion, latin, dalam konsep orkestra yang merupakan gabungan dari elemen musik rock dan orkestra.

\section{Pelaku Musik Simfoni}

Para pelaku musik simfoni di Indonesia dalam rangka mengeksistensikan dirinya sebagai kelas musik simfoni, dipengaruhi juga oleh orkes simfoni terkenal dari berbagai negara yang sudah mendunia kepopulerannya. Hal ini merupakan perjuangan untuk meraih klasifikasi yang berlangsung dalam suatu organisasi orkes simfoni, perjuangan bagi supremasi antara produksi dan publisitas, dan antara rancang bangun dan pemasaran. Kondisi seperti ini tidak dapat dipisahkan dari konflik nilai yang muncul, dan melibatkan cara pandang dunia secara keseluruhan bagi para partisipan dan seni kehidupan. Ini bukan saja distingsi kepentingan seksional, namun juga dalam hal karier skolastik yang berlainan. Melalui penampilan orkes simfoni asing dan melalui mereka, selanjutnya perbedaan wilayah rektuitmen sosial juga menjadi perbedaan akhir dalam habitus musik orkestra simfoni.

"......because they oppose not only different sectional interests but different scholastic and accupational careers and, through them, different social recruitment areas and therefore ultimate differences in habitus".

Pada saat keberadaan musik orkestra simfoni mulai populer, di sisi lain pada pada saat musik simfoni berkembang, hadir juga sebuah ekspresi musik simfoni ataupun tokoh musik simfoni yang berasal dari luar negeri dan hadir di Indonesia: Sejak 1960 RRI Jakarta waktu itu dipimpin Sukirman, menghidupkan Orkes Simfoni Jakarta, dengan konduktor tamu dari AS, Wheeler Backett. Maestro konduktor Hikotaro Yazaki (konduktor ini yang dianggap guru konduktor oleh Amir Katamsi konduktor OSJ yang ke empat) dari Jepang, mampu menggerakkan dan membesarkan Nusantara Symphony Orchestra (NSO) hingga mencapai tahap kemajuan yang cukup membanggakan. Begitu pula konduktor tamu Edward van Ness dari Amerika. Selain itu NSO banyak menghadirkan musisi ternama dari luar negeri: Hugo Holleman (pemain biola Belanda), Anthony Peebles (pemain piano Inggris), Lim Kek Beng (pemain cello Belanda asal Indonesia), Vivian Siao (pemain piano AS), Cecylia Barczyk (pemain cello AS), Miwako Fukushi (pemain harpschord Jepang), Kuei Pin Yeo (pemain piano Indonesia), Balazs Reti (pemain piano Hungaria), Alain Moglia (pemain biola Prancis), Robin Clavreal (pemain cello Prancis), Lertkiat Chongjirajitra (pemain trumpet Thailand), Casino Chomei (pemain piano Prancis), dan Adam Gyorgy (pemain piano Hungaria); Konduktor tamu Otto dari Austria Mayerhold, dan Mariama Djiwa Jenie di Audlitorium RRI mengisi acara pagelaran Orkes Simfoni Jakarta yang ke 6; Penampilan Orkes Simfoni NHK pertama tahun 1973, dan kedua tahun 1979. Selain itu yang datang ke Indonesia lainnya adalah: The New York Philharmonic Symphony Orchestra dengan konduktor Zubin Mehta (orang Israel), yang mengadakan pergelarannya pada bulan September 1984 dengan mengambil tempat di Balai Sidang Senayan Jakarta.

Banyaknya penyajian para pelaku musik simfoni asing di Indonesia, di mana kegiatan-kegiatan ini mentransformasikan nilai-nilai musik orkestra simfoni dari luar kepada musisi Indonesia khususnya, dan kepada pecinta musik orkestra simfoni pada umumnya. Mereka memberikan kontribusi besar dalam lanskap seni musik orkestra simfoni di kalangan kelas menengah di Indonesia. Melalui media permainan instrumen musik orkestra dan konduktor dengan tingkat ketrampilan yang tinggi, mampu membawa masuk ke dalam penghayatan rasa para pelaku musik simfoni di Indonesia secara mendalam.

Di tengah hingar-bingarnya kehidupan musik hiburan, pop, jazz dan lainnya, menimbulkan degradasi moral, krisis keteladanan, ketidakpastian sosial dan rendahnya edukasi dari pemerintah sebagai pemangku tugas dalam mencerdaskan kehidupan bangsa dalam bidang kebudayaan 
kesenian khususnya musik orkestra simfoni, membuat para pelaku musik rindu dan mendambakan kehadiran fenomena baru dalam rangka peningkatan kecerdasan para pelaku dan para calon pelaku musik simfoni. Pemikiran lain mengatakan bahwa dengan perlahan-lahan, salah seorang penggemar musik kerasukan pikiran jernih: tak ada ruginya berkenalan dengan karya J.S. Bach, Paganini, atau Mozart, yang kualitasnya rata-rata di atas kebanyakan musik pop.

Orkes Simfoni Jakarta tak sanggup menjadi tontonan dan tuntunan bagi pecinta dan grup-grup musik orkestra simfoni di Indonesia karena keberadaannya tidak dapat eksis yang disebabkan oleh berbagai faktor, misalnya masalah finansial dan pengkaderan yang tidak berjalan dengan semestinya. Suka Hardjana mengatakan pada awalnya OSJ dapat melaksanakan pergelaran sekali setiap bulan. Akan tetapi, kurangnya dana, minat masyarakat, tenaga ahli dan mungkin juga lemahnya sistem organisasi dan manajemen yang harus menopang eksistensinya, orkes simfoni satu-satunya di Indonesia ini menjadi kasihan jalannya. Dengan demikian, para pelaku musik simfoni berdiri sendiri-sendiri dan membuat corak, gaya, maupun karakter yang berbeda. Perkembangan musik simfoni menjadi menjamur dalam kuantitas,tetapi miskin dalam kualitas, hal ini seperti yang dikatakan oleh Adhidarma: Sewaktu penulis melakukan wawancara dengan Adhidarma, ia mengatakan bahwa untuk mendapatkan pemain alat musik tiup yang berkualitas cukup sulit.

Proses urbanisasi musisi orkestra simfoni tahun 1960 hingga tahun 1980-an ke kotakota, menyebabkan mereka terpisah dengan akar-akar tradisional mereka. Di wilayah urban yang baru, mereka jauh dari sumbersumber simbol tradisi yang dulu bersatu dengan jiwa mereka di kota kecil ataupun di pedesaan. Sebagai sebuah kelas menengah baru, mereka membutuhkan simbol-simbol musikal baru yang dapat mengikat dan sanggup mempertahakankan identitasnya. Ketika OSJ mempergelarkan penyajian musik simfonis dengan bagus menjadi harapan bagi musisi ataupun kelompok musik simfoni lainnya untuk mengikuti jejaknya. OSJ membangun sebuah genre musik modern dengan basis dan identitas musik kultural Barat. Genre musik modern ini memperkuat simbol-simbol pembentukan kelas yang sebelumnya disimbolkan oleh orkes-orkes pendahulunya seperti Orkes Radio dan Orkes Studio. Jika Orkes Radio berfungsi sebagai simbol BaratDalam wawancara dengan Adhidarma di Jakarta, dikatakan bahwa orkes Radio hanya memainkan repertoar-repertoar standar simfoni Barat. Sementara itu orkes Studio banyak memainkan repertoar yang berupa lagu-lagu Indonesia dan Orkes Studio sebagai simbol Timur, munculnya kelas musik orkestra simfoni pada OSJ dapat memberikan rasa estetis dalam selera musik dari kelas ini, di mana OSJ merupakan penggabungan antara Barat dan Timur. Karya seni dianggap sebagai barang simbolis (bukan sebagai aset ekonomis, meski bisa juga demikian) yang hadir sedemikian rupa bagi seseorang yang menguasai cara-cara menilainya, atau dengan kata lain mengurainya.

Pada perkembangan selanjutnya, prakarsa OSJ yang menyatukan simbol Barat (Orkes Radio) dan Timur (Orkes Studio) ini, kemudian diikuti oleh berbagai performan musik simfoni artistik yang lain. Nusantara Symphony Orchestra (NSO) misalnya, berusaha menampilkan sebuah musik simfoni yang profesional. Para pemainnya menanda tangani kontrak dengan pengelola NSO yang dimotori oleh Miranda Goeltom, pada sekitar pertengahan dekade 2000-an. Isi kontrak antara lain mengikuti latihan secara tetap dan tidak boleh mengikuti kegiatan orkestra lain, honor yang cukup besar (Agus Murtono yang waktu itu menjadi concert master mendapatkan honor sepuluh juta rupiah tiap bulannya). Setelah Miranda berhenti dari birokrat Bank Indonesia, berhenti pula sistem kontrak di NSO. Hal seperti itu dilakukan Miranda karena ketika ia mengambil studi tingkat master di Amerika, ia juga terlibat pada kegiatan New York Philharmonic Orchestra (NYPO). 
Pendanaan NYPO antara lain berasal dari Bank Sentral Amerika. NSO dalam setiap pergelarannya selalu menampilkan repertoar Barat dan Timur.

Para pelaku kelas musik orkestra simfoni merasa senang, terutama pemain musiknya. Dengan dikelolanya sebuah musik orkestra secara profesional, maka penghasilan pemain musik beserta dewan pengurus orkestra menjadi layak. Musik yang disajikan menjadi baik karena latihan mandiri dan kelompok yang ketat, menghasilkan sajian bunyi yang seperti diharapkan oleh penyaji maupun penikmat musik simfoni. Kondisi seperti ini dapat dikatakan bahwa manajerial orkes simfoni sudah dikelola secara profesional.

\section{Orkes Simfoni pada Lembaga Pendidikan Formal}

Pendidikan formal yang tertulis dalam judul sub-bab, berkaitan dengan konteks habitus Bourdieu. Pada strategi reproduksi kelas musik orkestra simfoni, serangkaian praksis yang berbeda dari individu ataupun keluarga, sadar atau tidak, cenderung menjaga atau memperbanyak aset mereka dan akibatnya, mempertahankan dan menaikkan posisi mereka dalam struktur kelas. Selanjutnya melalui mediasi watak terhadap masa depan, ditentukan adanya kesempatan reproduksi obyektif dari kelompok. Instrumen reproduksi sistem pendidikan, dengan sendirinya tergantung pada relasi kekuasaan antara kelas yang ada. Secara implisist atau eksplisit, itu semua merupakan strategi, habitus dengan wataknya, harapan subyektif dari probabilitas obyektif, dan reproduksi sosial.

"When class fractions who previously made
little use of the school system enter the race
for academic qualifications, the effect is to
force the groups whose reproduction was
mainly or exclusively achieved throuhg
education to step up their investments so
as to maintain the relative scarcity of their
qualifications and, consequently, their
position in the class structure. Academic
qualifications and the school system which
awards them thus become one of the key
stakes in an interclass competition which generates a general and continous grorwt in the demand for education and an inflation of academic qualification and inflation of academic qualificatins"(Pierre Bourdieu, 1986: 133).

Didirikannya Sekolah Musik Indonesia (SMIND) tahun 1952 dan Akademi Musik Indonesia (AMI) tahun 1964, telah menjadi kekuatan penggerak bagi proses musikalisasi orkes simfoni yang terjadi hampir di semua level sosial dan politik di kota-kota Indonesia. Para lulusan AMI banyak yang menjadi tenaga pengajar di berbagai pendidikan tinggi di Indonesia, misalnya di Universitas Negeri Yogyakarta, Universitas Negeri Semarang, Universitas Negeri Surabaya, UGM, ISI Padang Panjang, dan lain-lain. Saat perkembangan musik klasik sedang berlangsung, kelas menengah musik tumbuh menjadi kekuatan penting. Ketika kalangan menengah ini sedang mengalami mobilisasi vertikal, pemerintah membuka dirinya untuk mengakomodasi kekuatan yang sedang tumbuh ini. Kelas menengah musik simfoni pada periode ini mulai memiliki kekuatan memasuki pusat kekuasaan. Pejabat pemerintah dan birokrat kemudian mengalami apa yang disebut dengan musikalisasi birokrat.

Ali Sadikin Gubernur DKI (1966-1977), memprakarsai berdirinya Orkes Simfoni Jakarta, Gubernur DKI Surjadi Soedirdja (1992-1997), juga mendukung keberadaan OSJ. FX Sutopo sewaktu menjadi direktur pada Direktorat Pendidikan dan Kesenian yang berkedudukan di Jakarta, pernah menjadi konduktor tamu OSJ, Fuad Hasan yang menyukai musik klasik dan dapat memainkan instrumen biola menjadi menteri Pendidikan dan Kebudayaan, membantu Yudianto (konduktor OSJ) untuk mendirikan simfoni orkestra baru, Suwanto Suwandi seorang putra musikan Kraton Orchest Yogya, menjadi tenaga kesenian di TVRI, Muchtar Kusumaatmadja yang menyukai musik klasik menjadi menteri Luar Negeri, bahkan ia turut mensposori pendirian NSO dan membuka yayasan musik di Jakarta, Prof. Dr. Nugroho Notosusanto 
mantan mendikbud, dan ketika menjadi rektor Universitas Indonesia mendirikan orkestra simfoni Mahawaditra, Parni Hadi Direktur Utama Lembaga Penyiaran Publik RRI, berusaha membangkitkan kembali OSJ, Susilo Bambang Yudoyono sebagai presiden RI yang juga senang berolah musik, menghidupkan orkestra Gita Bahana Nusantara yang setiap tahun tampil pada hari kemerdekaan RI, dan lain-lain.

Melihat kondisi seperti itu kelas musik orkestra simfoni nampaknya menjadi berseri, tetapi dibalik itu semua, sangat disayangkan keberserian itu hanya bersifat parsial dan belum dapat menyentuh semua kelompok musik orkestra sendiri. Orkes Simfoni Jakarta yang dahulunya dihidupi Ali Sadikin dan Surjadi Soedirja, kelanjutan keberadaannya sangat memprihatinkan. Suka Hardjana (2004) mengatakan:

"Apabila tidak segera mendapatkan perhatian dan tindakan penyelamatan tidak dilakukan, kita boleh khawatir bahwa lambat tapi pasti, orkes ibu kota yang seharusnya dapat menjadi kebanggaan warganya itu akan ambruk bersama tiangtiang penyangganya. Persis bangunan peyot yang tinggal menunggu waktu. Perlu renovasi segera untuk penyelamatan Orkes Simfoni Jakarta".

Walaupun banyak birokrat yang menyukai musik, bahkan sering mementaskan musik orkestra, tetapi pendidikan seni musik yang ada belum tersentuh secara mendalam. Sebagai contoh ISI Yogyakarta yang memiliki Jurusan Musik, belum memiliki sebuah orkestra simfoni. Pada hal SDM yang ada sangat mencukupinya. Sejak berdirinya hingga sekarang pengadaan instrumentasi musik orkestra juga belum pernah diadakan. Untuk kegiatan orkestra yang sifatnya ad hoc atau sporadis, hanya digunakan alat-alat musik lama sumbangan dari pemerintah Jepang. Selain itu institusi-institusi formal seni musik, belum dapat mempergelarkan orkestra simfoni secara rutin (bulanan, mingguan) kepada masyarakat pecinta dan pendukung musik klasik.
Kegiatan-kegiatan musik simfoni di tanah air sangat ditunjang oleh SDM-SDM dari pendidikan seni, entah itu level sekolah menegah atas ataupun perguruan tinggi. Jika para SDM musik simfoni yang berasal dari ranah pendidikan tidak terlibat dalam konser musik simfoni, dapat dipastikan di Indonesia tidak akan ada orkes simfoni. Dengan cepat, kelas menengah musik orkestra simfoni ini telah berpengaruh besar dalam dinamika kehidupan musik orkestra di Indonesia. Kapan saja atau di mana saja di Indonesia ini diadakan pergelaran orkes simfoni, tentu para pelaku musiknya mayoritas pasti berasal dari hasil pendidikan seni secara formal.

Terlepas dari terjadinya birokratisasi faktor resiprokal (saling keterpengaruhan) antara pemerintah dan pelaku-pelaku musik simfoni, dapat dideskripsikan bahwa saling keterpengaruhan ini sebagai titik temu antara kondisi obyektif dan subyektif. Kondisi obyektif adalah diterimanya musik simfoni oleh pemerintah dengan berbagai cara dan kondisi musik simfoni yang menghendaki kelaikan sebagai bagian kebudayaan yang perlu dicerdaskan dan dikembangkan sesuai bunyi undang-undang dasar dalam hal memajukan kebudayaan bangsa. BAB XIII UUD 1945 yang sebelumnya berjudul Pendidikan kemudian hasil amandemen tanggal 10 Agustus 2002 tertulis Pendidikan dan Kebudayaan. Pasal 32 tertulis:

"Pemerintah memajukan kebudayaan
nasional Indonesia. Kemudian diganti (1)
Negara memajukan kebudayaan nasional
Indonesia ditengah peradaban dunia dengan
menjamin kebebasan masyarakat dalam
memelihara dan mengembangkan nilai-
nilai budayanya. (2) Negara menhormati
dan memelihara bahasa daerah sebagai
kekayaan budaya nasional."

Pada saat awal didirikannya sekolah seni musik, murid yang terdaftar sangat sedikit dan yang terjadi adalah sekolah mencari murid dan bukannya murid mencari sekolahan. Orang-orang tua waktu itu beranggapan hasil dari pendidikan seni musik hanya menjadi pengamen, pengamen di mata masyarakat 
termasuk pekerjaan rendahan yang kurang pantas untuk dicita-citakan. Ngamen dianggap masyarakat waktu itu (mungkin sekarang masih), hanya dilakukan oleh orang yang tidak atau kurang berpendidikan. Setelah Indonesia mengalami kemajuan dalam bidang industri dan ekonomi, kondisi sekolah seni menjadi berbalik. Mulai dari tahun 1990an hingga sekarang, animo masyarakat pada pendidikan musik sangat meningkat. Pada setiap pendaftaran mahasiswa baru di Jurusan Musik ISI Yogyakarta, jumlah para pendaftar berkisar tiga hingga empat kali kuota yang tersedia.

Awal tahun 1990-an, para sarjana seni musik dan para drop out-nya mulai bergerak keluar komunitas dirinya sehingga ekspresi musikalitasnya muncul di semua angkatan militer baik darat, laut, udara maupun angkatan kepolisian, di kantor-kantor, hotelhotel, bank-bank, birokrasi, dan sebagainya. Akan tetapi, ini pun baru sebagai fenomena sosial, mereka tampil tidak dalam bingkai orkes simfoni, melainkan tampil secara parsial instrumental baik secara individu maupun dalam kelompok kecil. Baru di tahun 2000-an lah, pengaruh dan nuansa politiknya mulai terasa. Susilo Bambang Yudoyono yang sudah sangat paham akan proses pembangunan kebudayaan, cukup bijaksana menangkap arus deras ini, ia kemudian mendukung pembentukan musik simfoni Gita Bahana Nusantara. SBY akan semakin mantap dalam berolah musik karena lagu-lagu yang diciptakannya dapat diiringi dengan musik orkestra simfoni. Pada kegiatan ini anggota orkes simfoni dan paduan suara dari berbagai tempat di seluruh Indonesia diseleksi ketat. Dari perspektif inilah, proses penghijaun atau menguatnya apresiasi musik dalam pemerintahan adalah sebuah proses alami dan akan berjalan terus karena musik sudah menjadi bagian dari kehidupan manusia. Hampir semua mobil ataupun transpotasi umum selalu tersedia alat pemutar musik, baik musik orkes simfoni ataupun musik jenis lainnya.

Derajat kopetensi agen seni musik salah satunya diukur berdasarkan pada tingkat penguasaannya atas seperangkat instrumen yang tersedia di waktu tertentu untuk mendaku karya seni. Instrumen-instrumen itu adalah skema-skema interpretasi yang jadi prasyarat untuk pendakuan modal seni musik, atau dengan kata lain, prasyarat bagi penguraian karya-karya seni yang ditawarkan kepada masyarakat tertentu dalam model tertentu. Kursus-kursus instrumen musik simfoni tersebar hampir di seluruh kota-kota di Indonesia, namun tidak di semua kota-kota terdapat musik orkestra simfoni. Berkembangnya kegiatan kursus instrumen musik simfoni ini seiring sejalan dengan semakin meningkatnya perekonomian yang terekam dalam semakin besarnya income per-capita di Indonesia.

Para alumnus pendidikan seni banyak yang membuat kursus-kursus instrumen musik simfoni secara parsial (privat), maupun melembaga (kursus piano, instrumen gesek, tiup, dan perkusi), di berbagai tempat di Indonesia. Akibatnya, banyak orang tua yang mengarahkan anaknya untuk mengenyam pendidikan musik secara langsung (melalui pendidikan formal) dan tidak langsung (melalui kursus). Pengiriman anak-anak ke pendidikan-pendidikan modern musik Barat merupakan basis dari munculnya generasi baru dan melalui jalan pendidikan modern inilah, anak-anak Indonesia masuk dalam kelas sosial baru yaitu kelas menengah musik orkestra simfoni.

Bourdieu mencermati bahwa untuk meraih dan kemudian mempertahankan posisi kelas dalam masyarakat, masyarakat modern tidak lagi mewariskan modalmodal material pada anak-anak mereka melainkan membekalinya dengan 'cultural capital' (modal kultural) berupa lingkungan belajar (keahlian musik, komputer, kursuskursus, dan lain-lain). Selanjutnya nilainilai pendidikan yang didapat dengan jalan memasukkan anak-anak mereka ke berbagai tingkat pendidikan, dimaksudkan untuk mendapatkan posisi sosial yang lebih baik di masyarakat. Melalui transfer modal kultural ini, anak-anak modern akan memiliki sejumlah keistimewaan-keistimewaan sosial 
sehingga dapat memasuki lingkaran-lingkaran elit masyarakat walaupun dengan absennya kekayaan individu.

Kekuatan simbolis agen pendidikan dalam kapasitasnya berhasil mendoktrinasi makna merupakan fungsi dari bebannya yang ada dalam relasi struktur kekuasaan. Tindakan pedagogis ketika memproduksi kebudayaan dalam segala kesemrawutannya, juga mereproduksi relasi kekuasaan yang menjamin keberlangsungannya. Hal ini merupakan fungsi reproduksi sosial dari reproduksi budaya. Tindakan pedagogis mencerminkan kepentingan kelompok atau kelas dominan, yang cenderung mereproduksi modal kultural secara tidak merata antar-kelompok atau antar-kelas yang hidup dalam satu ruang sosial, sehingga memproduksi struktur sosial.

Otoritas pedagogis merupakan suatu komponen atau prasyarat keberhasilan tindakan pedagogis. Otoritas ini adalah suatu kekuasaan arbitrer untuk bertindak, tanpa disadari oleh pelaku dan para penganutnya sebagai sesuatu yang legitimate. Legimitasi ini memungkinkan tindakan pedagogis beroperasi. Ini dialami sebagai sesuatu yang netral, atau bernilai positif, tetapi tidak ada tindakan pedagogis yang begitu mendasar atau bebas secara kultural. Otoritas pedagogis begitu fundamental sehingga dia seringkali secara implisit atau eksplisit dianggap sebagai hubungan alamiah atau primordial antara anak dan orang tua.

\section{Munculnya Berbagai Macam Orkes Simfoni di Indonesia}

Model Bourdieu adalah model di mana kekuasaan dan otoritas mengalir dari atas (pejabat) ke bawah. Reproduksi musik orkes simfoni menunjukkan keberhasilannya dan terus berlanjut dari hubungan dominasi yang ada di Indonesia. Banyaknya SDM praktisi musik orkes simfoni di Indonesia, khususnya di Jawa menarik minat para pemikir musik simfoni untuk mendirikan bangunan musik simfoni yang baru selain OSJ. Kevakuman yang melanda OSJ juga menjadi penyebab munculnya bangunan baru tersebut.
Bourdieu mengatakan bahwa kekuatan habitus berasal dari ketidaklengkapan perilaku dan habituasi, bukan pada aturan dan prinsip yang dipelajari secara sadar. Beberapa perilaku yang sesuai secara sosial diproduksi secara rutin, tanpa acuan eksplisit kepada pengetahuan yang terkodifikasi, dan tanpa aktor yang mengetahui secara pasti apa yang mereka lakukan (karena secara memadai mampu menjelaskan apa yang mereka lakukan).

Sejalan dengan pendapat itu di Indonesia banyak musik orkes simfoni yang lahir dan hidup hanya sementara waktu, dan akhirnya tak terdengar lagi kehidupannya. Menurut Suka Hardjana di Indonesia dikenal beberapa orkes simfoni baik yang tetap maupun yang musiman, umumnya orkes simfoni tersebut berada di kota-kota besar seperti Jakarta, Surabaya, Bandung, Yogyakarta, dan sebagainya. Sayang orkesorkes tersebut satu-persatu mati dan tidak diketahui riwayatnya lagi (Hardjana, 1993: 108). Twilite Orchestra (dan mungkin semua Orkes Simfoni di Indonesia) adalah sebuah pops orchestra, yaitu orkestra simfoni yang tidak hanya memainkan repertoar musik klasik saja, tetapi musik film, drama musikal, musik pop, dan tradisional yang diaransemen secara simfonik, telah didirikan pada tahun 1991. Selanjutnya pada bulan Pebruari tahun 1992, Twilite Orchestra sukses menggelar konser bersama David Foster di acara televisi RCTI.Twilite Orchestra sudah terdaftar sebagai anggota American Symphony Orchestra League sejak tahun 1995 dengan demikian keberadaan TO sudah bersifat internasional.

Gita Bahana Nusantara (GBN) didirikan oleh Departemen Kebudayaan dan Pariwisata tahun 2003 dalam bentuk orkestra dan paduan suara yang anggota-anggotanya terdiri dari para pelajar dan mahasiswa dari 33 provinsi. GBN didirikan sebagai upaya pemerintah untuk melestarikembangkan fenomena lagu nasional yang sarat dengan semangat jiwa heroisme dan patriotisme.

Perpaduan antara lagu nasional dengan instrumen musik modern dan ditata 
sedemikian rupa hingga menjadi suatu alunan nada dan irama dalam penyajian orkestra secara penuh. Gita Bahana Nusantara dibentuk sebagai upaya untuk melestarikan dan mengembangkan khasanah lagu nasional yang sarat dengan makna heroisme dan patriotisme. Paduan lagu nasional dengan instrumen musik modern, dan dikemas menjadi suatu alunan irama dalam pergelaran orkestra lengkap. Program ini kemudian dilanjutkan oleh Kementerian Pariwisata dan Ekonomi Kreatif.

Tahun 1983, tepatnya tanggal 11 Juni, Orkestra Simfoni Universitas Indonesia (OSUI) Mahawaditra didirikan. Nama Mahawaditra berarti suara yang agung, nama ini dicetuskan oleh Prof. Dr. Nugroho Notosusanto ketika itu menjadi Rektor Universitas Indonesia, saat pendiriannya bertepatan dengan peristiwa gerhana matahari total di Indonesia.

Kemunculan Orkes Simfoni Jakarta, dan bangunan-bangunan musik simfoni lainnya di berbagai tempat di kota metropolitan Jakarta, memperlihatkan bahwa Jakarta mulai menunjukkan kepribadiannya sebagai kota metropolitan. Bourdieu mengatakan seolah-olah setiap arena membangun habitus spesifiknya sendiri dalam konteks tempat. Di mana-mana, tampaknya aktor membawa ke arena manapun tempat mereka menjadi bagian dari hidup dan habitus mereka yang disusun secara historis.

Pemunculan bangunan musik orkestra tidak hanya di Jakarta saja, musik orkestra juga muncul di berbagai tempat dan di berbagai kota di luar Jakarta, di antaranya orkes Cisya Kencana dari Yogyakarta, Orkes Simfoni RRI Bandung, Surabaya Simphony Orchestra, dan lain-lain. SSO didirikan atas prakarsa pengusaha Surabaya Suwaji, yang ketika di Amerika menyaksikan pergelaran New York Philharmonic Orchestra dan akhirnya ia tertarik untuk mendirikan orkes simfoni di Surabaya. Selanjutnya SSO pada tahun 1998 menggelar konser perdananya di Ballroom Hotel Westin Surabaya, dengan 120 orang anggota koor dan 60 orang pemain orkestra. Pada konser perdana menampilkan musisi-musisi asing, dari Korea Selatan, Hongkong, dan Filipina.

\section{SIMPULAN}

Munculnya kelas musik orkes simfoni dari era 1960-an hingga sekarang adalah sebagai hasil dari proses panjang hubungan kebudayaan musik dan pemerintah. Pada tahun 1950-an, telah dibuat kesepakatan Yusuf Ronodipuro dan Presiden Sukarno bahwa lagu kebangsaan Indonesia Raya diiringi dengan orkestrasi musik orkestra simfoni. Sebelum itu terjadi, banyak pejuang dan cendikiawan Indonesia yang mendapat pendidikan apresiasi musik Barat di sekolahsekolah Belanda. Dengan didirikannya pendidikan musik Barat di Indonesia baik formal maupun non-formal, masyarakat pribumi mulai cerdas dalam hal musik Barat, banyak dari mereka yang meningkatkan kecerdasannya dengan melanjutkan studi musiknya ke negara-negara yang musik orkestranya maju, selanjutnya ilmu yang didapatnya ditransformasikan kepada masyarakat secara luas.

Keberadaan orkestra simfoni di Indonesia pada awalnya dimiliki oleh kolonial. Belanda yang memang ditujukan untuk masyaraat kolonial dan orang asing yang berada di indonesia waktu itu. Pada perkembanganya, masyarakat Indonesia sedikit demi sedikit mulai tertarik pada jenis kesenian baru tersebut. Seiring dengan tumbuh baiknya tata ekonomi, politik, sosial, maupun budaya, membuat orkestra simfoni tidak lagi sebagai budaya Barat saja, tetapi sudah menjadi budaya universal dan menjadi salah satu aset tata pergaulan antar-bangsa. Temuan dalam penelitian ini adalah bahwa orkestra simfoni di Indonesia adalah produk poskolonial yang kemudian dapat diterima oleh masyarakat Indonesia sebagai budaya baru dengan diawali oleh pengorkestrasian lagu kebangsaan Indonesia Raya. Hingga kini garapan secara orkestra tersebut dapat didengarkan melalui berbagai media audio mapun audio visual sebagai tune pembuka ataupun penutup siaran mereka. Akhirnya Orkes Simfoni Jakarta sebagai produksi 
awal orkestra di Indonesia, para pelaku dan pendukung musik orkestra telah berhasil membentuk kelompok kelas menengah orkes simfoni, selanjutnya mereproduksi orkes simfoni dengan berbagai nama dan diberbagai tempat. Hal ini sejalan dengan teori 'habitus'yang dikemukakan oleh Pierre Bourdieu.

\section{DAFTAR PUSTAKA}

Biantoro, Kris.2006. Manisnya Ditolak. PT Gramedia Pustaka Utama: Jakarta.

Bourdieu, Pierre.1986. Distinction A Social Critique of The Judgement of taste. trans.Richard Nice. T.J. Press (Padstow):Great Britain.

Bourdieu, Pierre.1977. An Outline of a Theory of Practice. trans. Richard Nice. Cambridge University Press:Cambridge.

Bourdieu, Pierre. 2012.Arena Produksi Kultural, Sebuah kajian Sosiologi Budaya, judul asli, 'The Field of Cultural Production:Essays on Art and Literature', terj. Yudi Santosa. Kreasi Wacana: Yogyakarta.

Ensiklopedi Jakarta, Budaya dan Warisan, dalam http://www.jakarta.go.id/ jakv1/encyclopedia/detail/1245.15 Nopember 2013.

Ganap, Victor. 2000. “Konser Simfoni Musik Peradaban" dalam Jurnal Seni.BP ISI Yogyakarta: Yogyakarta.

Garraghan, Gilbert J. 1957. A Guide to Historical Method. East Fordham University Press:New York.

Hardjana, Suka. 2001. "Ragam", dalam Majalah Gatra Nomor 34 Jakarta: Senin 9 Juli. 2004. Esai \& Kritik Musik. Galang Press: Yogyakarta.

Hardjana, Andre. 1993. “Kecenderungan Masyarakat Di Masa Datang Dalam Konteks Kebudayaan" dalam Jurnal Seni III/01 (Januari). BP ISI Yogyakarta:Yogyakarta. http:/ / majalah.tempointeraktif.com/id/ arsip/1979/09/08/ms/mbm.19 790908. ms 55136.id. html. 10 Oktober 2010.

http:/ / majalah.tempointeraktif.com/id/ arsip/1984/02/11/MS/mbm.19 8402 11.MS 43461.id.html. 12 Nopember 2012.

http:// www.jakarta.go.id/web / encyclopedia/detail/1245/JosCleber. 30 Maret 2012.

http:/ / www.jakarta.go.id/jakv1/ encyclopedia/detail/1245. 12 Desember 2012.

http:/ / www.tokohindonesia.com/biografi/ article/286-direktori/2625-kon duk tor-pendiri-twilite-orchestra. 13 Nopember 2013.

http:/ / www.ultimoparadiso.com / alunan-gita-bahana-nusantaralecut-semangat persatuan.html. 13 Nopember 2013.

Ingram, Richard T. 1996.Ten Basic Responsibilities of Nonrprrofit Boards, NCNB Governance Series, No.1, National Center for Nonprofit Board, Revised: Washington D.C.

Jenkins, Richard.2013. Membaca Pikiran Bourdieu. Kreasi Wacana:Yogyakarta.

Kuntowijoyo. 2006.Budaya dan Masyarakat. Tiara Wacana: Yogyakarta.

Perpustakaan Negara Malaysia. 2011. Gemilang 50 tahun Orkestra RTM 19612011 (Malaysia:Jabatan Penyiaran Malaysia (RTM) Kementerian Penerangan Komunikasi dan Kebudayaan).

Pergelaran OSJ tanggal 27 Januari 2010 di Lt. 2 RRI Jakarta, Buklet.

Pergelaran JPO tanggal 4 Juli 2004 di Gedung Kesenian Jakarta, Buklet.

Pergelaran NSO tanggal 5 Oktober 2009 di Balai Sarbini Concert Hall, Buklet.

Pergelaran JCO tanggal 14 September 2013 di Aula Simfonia Jakarta, Buklet. 
Pergelaran Jakarta Concert Orchestra tanggal 14 September 2013, Buklet.

Pergelaran OSJ tanggal 1 Juli 1993 di Gedung Trade Mart LT. VI Arena Pekan Raya Jakarta (PRJ) Kemayoran Jakarta, Buklet.

Richard Jenkins. 2013. MembacaPikiran Pierre Bourdieu,KreasiWahana: Yogyakarta. hlm.106-117.

Sri Edi Swasono dalam http://www. suarapembaruan.com/New 2008/ 01/ 04/ Editor/edit02. html. 10 Oktober 2012.
Soedarsono, R.M. 2002.Seni Pertunjukan Indonesia di Era Globalisasi.Gadjah Mada University Press: Yogyakarta.

Tong, Solomon. 2009. Musik Klasik Tak Akan Pernah Mati. Jaring Pena: Surabaya.

Undang-Undang Dasar 1945, Palito Media.

215. IM Z 132750 .id.html, 12 Nopember 2012.

\section{NARASUMBER}

1. Adidharma konduktor OSD Jakarta, 74 tahun.

2. Agus Murtono, 60 tahun pimpinan Orkes RRI Surakarta. 